\title{
Application of Silica Supported Calix[4]arene Derivative as Anti-reversion Agent in Tire Tread Formulation
}

\author{
Hediye Mohamadi, ${ }^{1}$ Fereshteh Motiee, ${ }^{1, \star}$ Saeed Taghvaei-Ganjali ${ }^{1}$ \\ and Mandana Saber-Tehrani ${ }^{1}$ \\ ${ }^{1}$ Chemistry Department, IA-University, North Tehran Branch, Tehran 1651153311, Iran \\ *Corresponding author: E-mail:f_motiee@iau-tnb.ac.ir \\ Phone: +9877009800
}

Received: 06-27-2020

\begin{abstract}
In this research the influence of the silica supported calix[4]arene derivative (SS-Calix) on the reversion resistance, mechanical properties and thermal behavior of NR/BR tire tread formulation was investigated by the oscillating disc rheometer, FTIR, TGA and tensile testing. The results revealed that the reversion behavior of NR/BR vulcanizate is affected by SS-Calix. The data obtained from curing characteristics and thermal stability of test pieces indicate that, SS-Calix acts as an anti-reversion for rubbery materials that are exposed to thermal shock in the early stages of temperature rise. It's predicted that these results are due to the interaction between the $\mathrm{OH}$ groups present in the SS-Calix surface and the carbon of the polymer chains. The broad peak observed in the IR spectrum around $1824 \mathrm{~cm}^{-1}$ which is referred to $\mathrm{C}=\mathrm{O}$ bond, confirms this prediction. In addition, the presence of SS-Calix in compound causes to increase modulus and hardness but reduce elongation and resilience.
\end{abstract}

Keywords: Mechanical properties; rubber; thermal properties; tire tread formulation; silica supported calix[4]arene; perkalink900.

\section{Introduction}

Reversion refers to the loss of crosslink density. It occurs especially in compound containing natural rubber (NR) and some synthetic rubber (Isoprene Rubber) when polysulphidic crosslinks are exposed to temperature time procedure which causes breakdown of polysulphidic crosslinks to di-sulfides and mono-sulfides crosslinks. This occurrence leads to a reduction in crosslink density and consequently loss of functional properties of rubber products.

The best method for evaluation of the reversion is based on rheometer torque curves. In this curves, the negative slope indicates the reversion phenomenon. ${ }^{1,2}$ Since reversion decline modulus and mechanical properties of the compound, there are some approaches in the industry to reduce it. One of these methods is the applying of efficient (EV) and semi-efficient (Semi-EV) vulcanization systems. The crosslinks created by these curing systems are usually mono-sulfide and disulfide type which has a higher thermal stability compared to polysulfide cross- links. ${ }^{3,4}$ Efficient (EV) and semi-efficient (Semi-EV) vulcanization systems improved mechanical properties and thermal aging characteristics, but because the length of the mono and disulfide bonds is less than the polysulfide, the flexibility and fatigue life of rubber compounds are reduced. ${ }^{5}$ Also in such curing systems due to faster cure rates and lower total sulphur levels the adhesion of rubber to metal and rubber to fabric is very low. ${ }^{6}$ One of the approaches used to control the reversion phenomenon is the employing of anti-reversion agent. Perkalink900 (1, 3bis-citraconimidomethyl benzene) is the most commonly used anti reversion agent in the rubber industry. Perkalink900 prevents loss crosslink density by creating new crosslinks through the well-known Diels-Alder reaction (Figure 1). ${ }^{7,8}$

In recent years, there have been numerous studies on the reversion and its kinetic. ${ }^{910}$ In 2019, Nah et al. vulcanized chlorobutyl rubber and applied 4, 4'-bis (maleimido) diphenyl methane (BMDM) as a crosslinking agent. They examined rheometric curves and reported that 


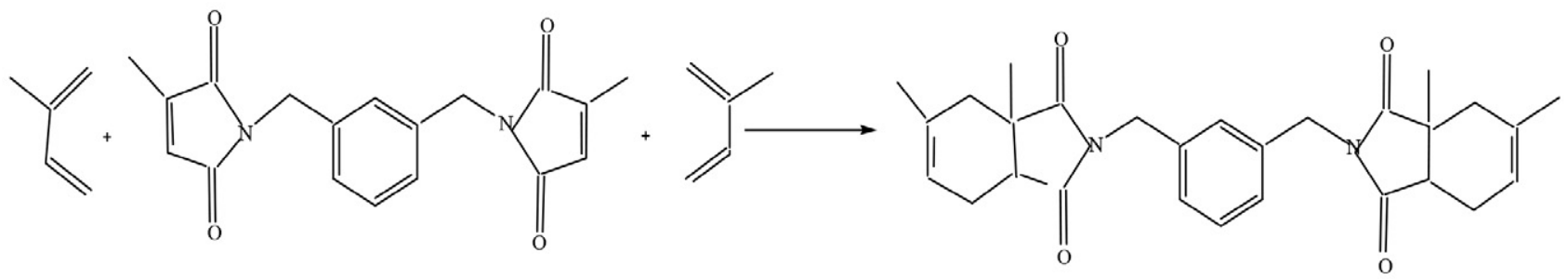

Figure 1. Creating new crosslinks by Perkalink $900^{8}$

BMDM significantly enhanced the reversion resistance. ${ }^{11}$ In 2016, they applied BMDM in NR vulcanized with sulphur and described that the presence of $5 \mathrm{phr}$ of BMDM significantly improves reversion resistance without adversely affecting the scorch time and cure rate. It also enhancement crosslink density and drops compression set value. ${ }^{12}$ In 2017, Sousa et al. revealed that the presence of devulcanized rubber chain in the compound has a deleterious effect on the mechanical properties of curing blends. ${ }^{13}$ In 2015, Milani et al. invented new approach to determine reversion kinetic constants. ${ }^{14}$

Calixarenes is a macromolecule with hydrophobic cavities which represent one of the most studied host systems known as host-guest chemistry. Calixarenes and their derivatives have many applications in membrane electrodes, construction of polyurethane foams and composites, remove ions, sensors, catalyst, adsorption, binders, detection and extraction. ${ }^{15-21}$ In rubber industry, they used as filler, ${ }^{22}$ coupling agent, ${ }^{23}$ tackifier resin, ${ }^{24}$ adsorbent of CBS, DPG ${ }^{25}$ and antioxidant. ${ }^{26}$

Prevent the reversion phenomenon using anti-reversion agents has been investigated by different researchers, while the possible influence of calixarenes as anti-reversion element have not been properly studied in the existing literature. In this project, attempt has been made to investigate the role of silica supported calix[4]arene (SS-Calix) as an anti-reversion agent in tire tread formulation based on NR/ BR blends. The SS-Calix was prepared according to available source ${ }^{22,27}$ and applied as an anti-reversion agent in rubber specimens. The anti-reversion value of vulcanized samples was assessed by comparing the rheometric curves of blends containing SS-Calix and Perkalink900.

\section{Experimental}

\section{1. Materials}

NR (SMR-20) was provided from Teh Ah Yau Rubber Factory (Malaysia). BR (High Cis-96\%) was purchased by Shazand Petrochemical Company (Iran). Carbon Black 660 was supplied by Doodeh Sanati Pars Company (Iran). The commercial Silica (Ultrasil VN3) was supplied by Evonik Company (Germany). Aromatic oil was purchased from Iranol Co. (Tehran, Iran). Silane (Si69) was supplied by Shin-Etsu (japan). $\mathrm{ZnO}$ was provided from Shokohiye zinc oxid (Iran). Stearic Acid was supplied by AcidChem
Company (Malaysia). Sulfur (OT-20) and other ingredients including accelerators were purchased from Taizhou Huangyan Donghai Chemical Co., Ltd. (China). Wax was provided from behran Factory (Iran). Perkalink 900 was supplied by RheinChemie Company (Germany). 25, 26, 27,28 - tetrahydroxy - 5,11,17, 23 - tetrakis [cholorosulfonyl] calix[4]arene (SS-Calix) was prepared according to the literature. ${ }^{22,27}$ Para tert-butyl phenol, hydrochloric acid, diethyl ether, sodium hydroxide, chloro sulfonic acid, di chloro methane, di phenyl ether were provided from Merck company (Germany) and formaldehyde, acetic acid, ethyl acetate, xylene and acetone were purchased from Mojalali company (Iran).

\section{2. Preparation of Rubber Compounds}

The SS-Calix was introduced to the blends as a novel anti-reversion agent, along with accelerated sulfur for the Semi-EV vulcanization of NR/BR compound. The tire tread formulation of the rubbery samples which has been used in this study is shown in Table 1.

The compound that contains silica as filler, silane as coupling agent is designated as SP1 and it is used as control. The specimen that contains silica as filler, silane as coupling agent and Perkalink900 as anti-reversion agent is designated as SP2. SS-Calix is introduce to SP3 compound as filler, coupling agent and anti-reversion agent. Mixing was performed in a laboratory size two roll mixing according to ASTM D3184.

SP1 sample preparation: Natural rubber was initially masticated for 2 minutes then Butadiene Rubber was loaded into the roll mixing. Silica, Si69, aromatic oil and carbon black were added and mixed. Subsequently, the other ingredients: $\mathrm{ZnO}$, stearic acid, TMQ, 6PPD and wax were added and mixed. In the second stage, sulfur, TBBS were added to the compound.

SP2 sample preparation: Preparation of SP2 sample is similar to SP1 sample. Only in the final stage, perkalink 900, in addition to sulfur and TBBS, were added to the blend.

Although, in samples SP1 and SP2, the amount of carbon black ( $46 \mathrm{phr}$ ) is higher (almost 3 times) than sili$\mathrm{ca}$, however, in order to ensure the salinization of the blend, the mixing operation was performed for a longer period of time and at the maximum possible temperature compared to sample SP3 
Table 1. Compound Formulations

\begin{tabular}{lccc}
\hline $\begin{array}{l}\text { Ingredient } \\
\left(\mathbf{p h h r}^{*}\right)\end{array}$ & SP1 & $\begin{array}{c}\text { Sample } \\
\text { SP2 }\end{array}$ & SP2 \\
\hline NR & 70 & 70 & 70 \\
BR & 30 & 30 & 30 \\
Carbon Black 660 & 46 & 46 & 46 \\
Aromatic Oil & 15 & 15 & 15 \\
ZnO & 3 & 3 & 3 \\
Silica Ultrasil VN3 & 17 & 17 & - \\
Si69 & 0.5 & 0.5 & - \\
Perkalink900 & - & 1 & - \\
SS-Calix & - & - & 17 \\
Stearic Acid & 1 & 1 & 1 \\
TMQ & 1 & 1 & 1 \\
6PPD & 1 & 1 & 1 \\
Wax & 2 & 2 & 2 \\
TBBS & 1.75 & 1.75 & 1.75 \\
Sulphur & 1.4 & 1.4 & 1.4 \\
\hline
\end{tabular}

${ }^{*}$ phr represented the mass parts per 100 mass parts of NR/BR blend

SP3 sample preparation: In the first stage, natural rubber and butadiene rubber was masticated by laboratory two roll-mills of 8 inch diameter and 20 inch length. Following the compounding process, SS-Calix and carbon black added to the blend, then other components (aromatic oil, wax, stearic acid, zinc oxide, TMQ, 6PPD) except curing agents mixed with performing ingredients. Finally, the curatives (sulfur, TBBS) were added to the compound.

The compounding of this sample at a maximum temperature of $75^{\circ} \mathrm{C}$ lasted approximately 30 minutes.

At all stages, the materials that falls on the tray under the rollers was collected by the brush and added again to the compounds. After mixing, in order to rest the compounds and control the expansion or shrinkage of polymer chain, samples were stored at room temperature for $24 \mathrm{~h}$.

\section{3. Measurements}

\section{3. 1. Determination of Crosslink Density}

The swelling tests were used to calculate the crosslink density of three different rubber vulcanisates according to ASTM D471. The rubber pieces were cut from the compression-molded rubber sample weighting about $0.2-0.25 \mathrm{~g}$, and swollen in toluene to reach equilibrium, which took 72 hours at room temperature. The cured test pieces were taken out from the liquid, the toluene was removed from the sample surfaces wiped with tissue paper, the weight after swelling were measured. The samples were then dried in the oven until constant weights were obtained. The swelling results were used to calculate the crosslink density by applying the Flory-Rehner manner [equation (1)]. ${ }^{28}$

$$
v=\frac{-\ln \left(1-v_{2}\right)+v_{2}+\lambda v_{2}^{2}}{v_{1}\left(v_{2}^{\frac{1}{3}}-\left(\frac{v_{2}}{2}\right)\right)}
$$

Where $V_{1}$ is the molar volume of the solvent and $V_{2}$ is the volume fraction of rubber in the swollen. $\lambda$ is an interaction parameter between the polymer and the swelling agent.

\section{3. 2. Cure Characteristics}

The curing behavior of specimens was investigated from the torque curves generated by a Monsanto Moving Die Rheometer HIWA900 MDR (HIWA, Iran) at $160^{\circ} \mathrm{C}$.

\section{3. 3. Mechanical Properties}

Specimens were cut from vulcanized blends with 2 $\mathrm{mm}$ thickness. The tensile strength and tear resistance test were carried out by using a tensile tester (Testometric M350) at room temperature according to ISO37. Hardness of the vulcanized was determined according to the ASTM D2240 method by ShoreA (Bareiss, Germany). Resilience was measured by Hiwa300 (HIWA, Iran) according to DIN 53512.

\section{3. 4. Thermal Gravimetric Analysis (TGA)}

In order to understand the thermal stability of samples, thermo gravimetric analysis was performed on the TGA-SF1 (Mettler, Switzerland) apparatus using $15 \mathrm{mg}$ samples in the temperature range $25-800^{\circ} \mathrm{C}$ and under nitrogen atmosphere, at a heating rate of $10^{\circ} \mathrm{C} / \mathrm{min}$.

\section{3. 5. Fourier Transform Infrared Spectroscopy (FTIR)}

Fourier transform infrared spectroscopy (FTIR) was obtained by Bruker FTIR spectrometer (Germany).

\section{Result and Discussion}

\section{1. Crosslink Density}

The crosslink densities of the NR/BR composite were designated by the Flory-Rehner manner [equation (1)]. The results are presented in Table 2. As it can be seen the SP3 specimen have the most great crosslink density. This observation is due to the role of SS-Calix as filler and coupling agent and form more crosslinks. This is due to the interaction between the $\mathrm{OH}$ groups present in the SS-Calix structure and the rubber chains. The formation of $\mathrm{C}=\mathrm{O}$ bonds observed in the IR spectrum of the samples is the evidence of this incident.

Table 2. The results of crosslink density of three different samples

\begin{tabular}{lccc}
\hline & \multicolumn{3}{c}{ Sample } \\
& SP1 & SP2 & SP3 \\
\hline $\begin{array}{l}\text { Crosslink Density } \\
\left(\times 10^{-4} \mathrm{~mol} / \mathrm{cm}^{3}\right)\end{array}$ & 2.0812 & 2.596 & 2.9395 \\
\hline
\end{tabular}




\section{2. Cure Characteristics}

The best well-known compounding method to minimize reversion is the application of anti-reversion agents, thereby diminishing the number of polysulphidic crosslinks and generating reversion resistant mono and disulphidic crosslinks. The curing behavior of three various resulting materials is displayed in Figure 2. The cure rate index (CRI), the difference between maximum and minimum torque $(\Delta \mathrm{M}=\mathrm{MH}-\mathrm{ML})$, scorch time $\left(\mathrm{ts}_{2}\right)$ and optimum cure time $\left(\mathrm{tc}_{90}\right)$ are listed in Table 3 and Figure 3. The start time of the reversion is reported in Table 4 and its value at different times is shown in Table 4 and Figure 4.

The role of $\mathrm{ZnO}$ as activator depends on the type of rubber matrix and accelerator. The mechanism of zinc cat-

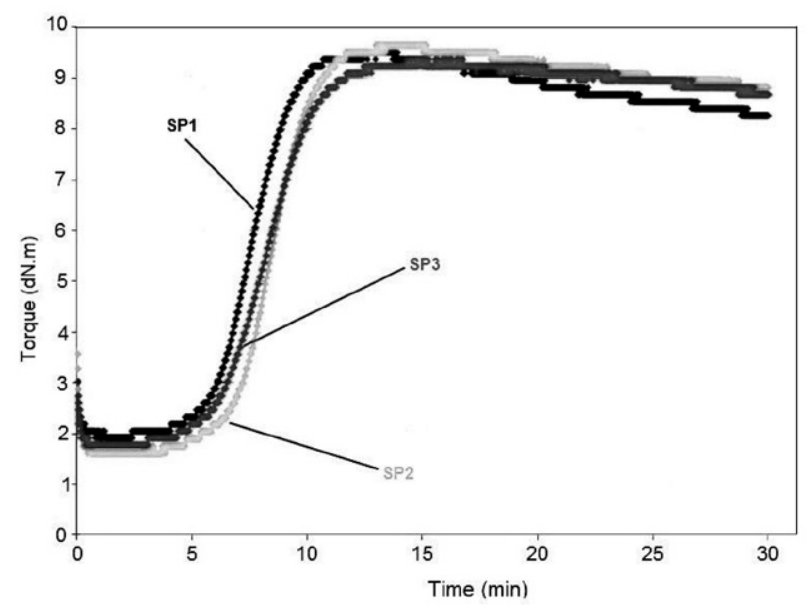

Figure 2. The curing curve of compounds based on NR/BR for SP1, $\mathrm{SP} 2$, and SP3

Table 3. The results of curing behavior of three different samples

\begin{tabular}{lrrr}
\hline & \multicolumn{3}{c}{ Sample } \\
& SP1 & SP2 & SP3 \\
\hline $\mathrm{ts}_{2}$ (Min) & 6.69 & 7.09 & 7.55 \\
$\mathrm{tc}_{90}$ (Min) & 9.32 & 10.59 & 10.13 \\
$\mathrm{CRI}$ & 35.52 & 28.58 & 7.59 \\
$\Delta \mathrm{M}$ & 7.59 & 7.59 & 8.01 \\
\hline
\end{tabular}

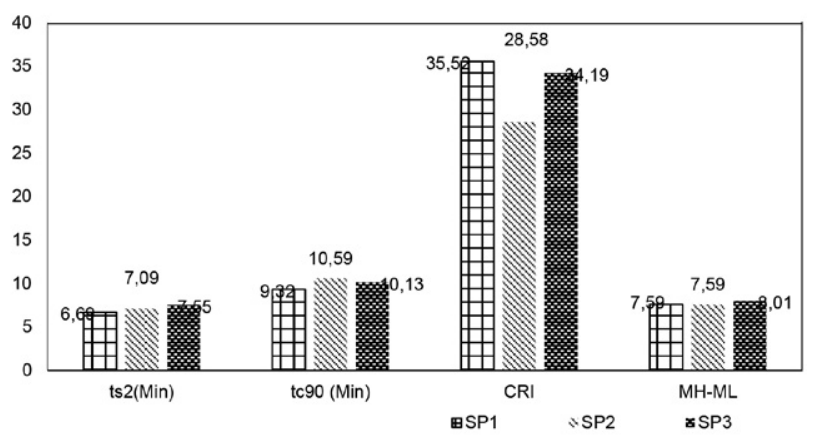

Figure 3. The curing characteristics of NR/BR blends
Table 4. Time to start the reversion and the value of reversion at different times for three various samples

\begin{tabular}{lccc}
\hline & \multicolumn{3}{c}{ Sample } \\
& SP1 & SP2 & SP3 \\
\hline TSR $^{*}$ (min) & 14 & 15 & 15 \\
Revt14 (dN.m) & 0.14 & 0.00 & 0.00 \\
Revt15 (dN.m) & 0.28 & 0.14 & 0.14 \\
Revt16 (dN.m) & 0.28 & 0.14 & 0.14 \\
Revt17 (dN.m) & 0.42 & 0.28 & 0.14 \\
Revt18 (dN.m) & 0.42 & 0.28 & 0.28 \\
Revt20 (dN.m) & 0.69 & 0.28 & 0.42 \\
Revt22 (dN.m) & 0.83 & 0.28 & 0.42 \\
Revt24 (dN.m) & 0.97 & 0.41 & 0.56 \\
Revt26 (dN.m) & 1.11 & 0.55 & 0.69 \\
Revt28 (dN.m) & 1.11 & 0.55 & 0.69 \\
Revt30 (dN.m) & 1.24 & 0.69 & 0.83 \\
\hline
\end{tabular}

${ }^{*}$ TSR: The start time of Rev (min)

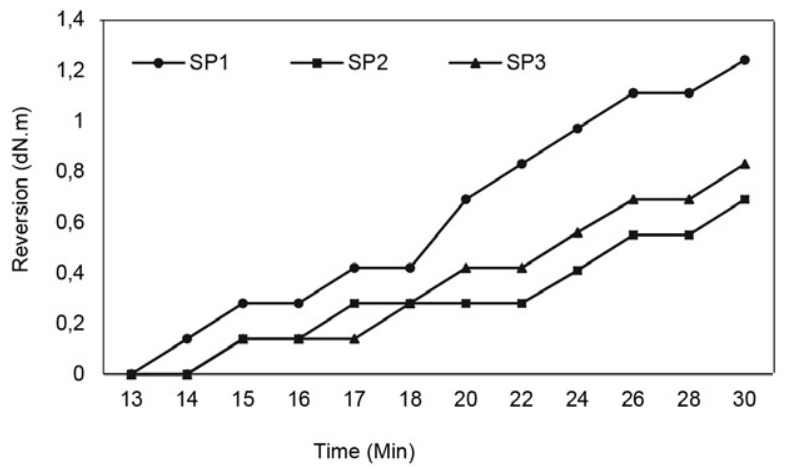

Figure 4. The reversion value of NR/BR blends at different times

alyzed sulfur vulcanization is very complex, but zinc-based complexes play a main role in determining the nature of the cross-linked products.

Formation rate of zinc-accelerator complex determines scorch time of rubbery materials. ${ }^{1}$ As shown in Figure 3, the maximum scorch time value is related to SP3 compound which treated by SS-Calix as an anti-reversion agents. The reason for this increase could be the physical interact of accelerators with the SS-Calix cavities. ${ }^{22} \mathrm{Be}$ cause of this, the formation of zinc-accelerator complex has delay and it caused to increases the scorch time. Another result of the rheometer's curve is $5 \%$ increase of $\Delta \mathrm{M}$ in the SP3 specimen over the other two compounds and it indicates despite delayed, accelerator act its effect as good as before. $\Delta \mathrm{M}$ indirectly indicates the crosslink density of rubber samples, an increase in $\Delta \mathrm{M}$ and crosslink density in SP3 compound demonstrates an improvement in the curing properties of test pieces. As can be seen, the tc $c_{90}$ in SP3 and SP1 compounds are approximately equal but in SP2 (contain Perkalink900), $\mathrm{tc}_{90}$ has increased so the cure rate index (CRI) has drastically decreased. This decrement in curing rate can be attributed to the negative effect of Perkalink900 on the rate of vulcanization. 
Another important and delicate point that can be considered from the torque curve of these three compounds is their reversion behavior which is significantly different at a certain time. The onset of reversion and its relationship with increasing curing time can be seen in Table 4 and Figure 4 for all samples.

As the rheometer curves displayed the onset of reversion in SP1 sample is earlier than two other samples. In SP2 and SP3, the reversion begins simultaneously, but then it behaves differently. As can be seen from the results, at $t_{17}$ of curing, the lowest amount of reversion (0.14 $\mathrm{dN} . \mathrm{m}$ ) is related to SP3. At the same time, the reversion of SP1 and SP2 is three times and twice that of SP3, respectively.

However, at $\mathrm{t}_{18}$, reversion of SP1 and SP 3 increases, but the value of this phenomenon in SP2 remains unchanged up to $\mathrm{t}_{22}$. At this point SP2 and SP3 samples have the same reversion resistant. The reversion of SP1 and SP3 will be increased after $t_{20}$. The highest value of reversion is related to SP1 and the lowest is belonging to SP2 blends. This trend is continued and indicated the anti-reversion behavior of three samples as fallowed (Figure 4): $\mathrm{SP} 2>\mathrm{SP} 3>\mathrm{SP} 1$

As Figure 4 shows, the point to consider in this phenomenon is the performance of SS-Calix in SP3 blend as an anti-reversion agent in a certain curing temperature range $\left(t_{15}-t_{17}\right)$. It seems that SS-Calix, in addition to being reinforcing filler that does not require a coupling agent ${ }^{22}$, it can be act as anti-reversion agent in rubbery materials that exposed to thermal shock. In fact, it acts as an anti-reversion in the early stages of temperature rise for rubbery materials that are exposed to thermal shock.

It is predicted that at the first 2 minutes of reversion, the polymer chains which crosslinks have been broken and radicalized by the reversion phenomenon form new positive interaction with the radicals created in the SS-Calix. As a result, it reduces the reversion. Because a limited number of calix moieties are bonded to the silica surface, over time, the number of calixarenes radicals on the silica surface are finished and the radical reaction of SS-Calix with elastomer chains are quenched. As a result, the anti-reversion effect of SS-Calix decreases through the time. In general, it can be suggested that the ability of Perkalink900 as an anti-reversion is slightly higher than the SS-Calix agent. In Table 5 the influence of the type of anti-reversion agents on the mechanical properties of resulting materials is shown.

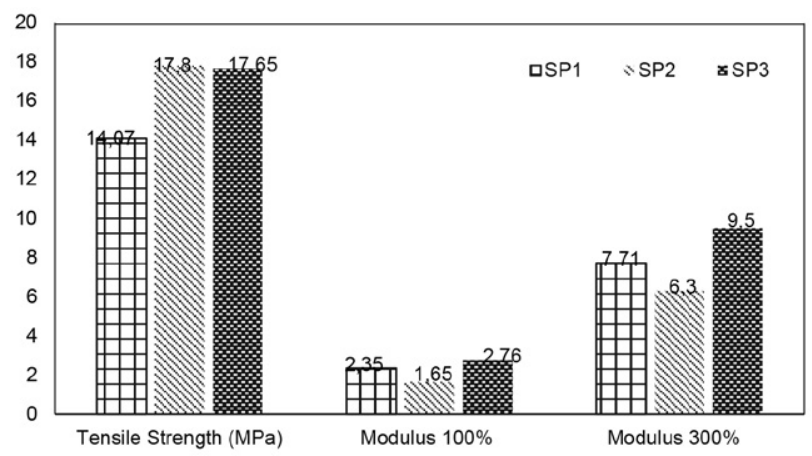

Figure 5a. Results of tensile strength, modulus $100 \%$ and modulus $300 \%$ for SP1, SP2 and SP3

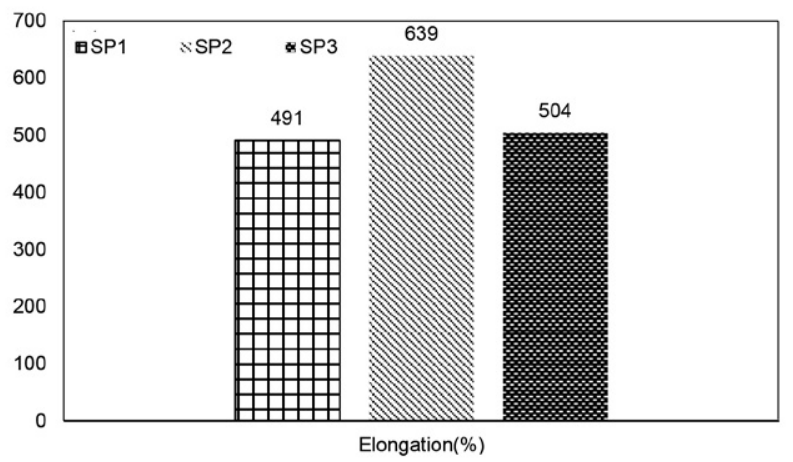

Figure 5b. Results of the elongation for SP1, SP2 and SP3

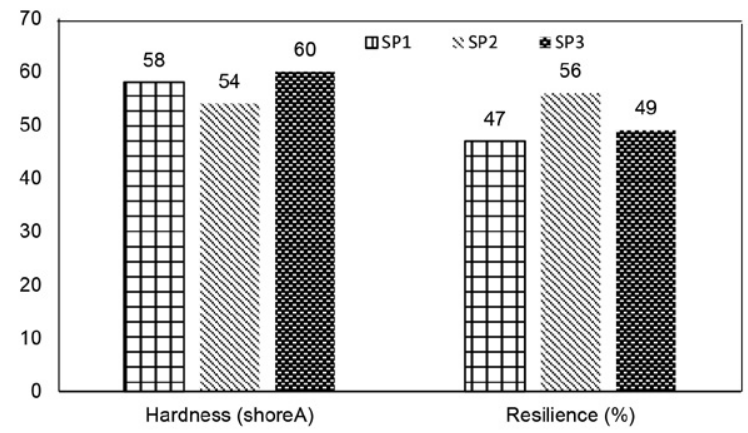

Figure 6. Results of hardness and resilience for SP1, SP2 and SP3

The results of the tensile strength, modulus $100 \%$, modulus 300\% are displayed in Figure 5a and the result of the elongation is shown in Figure 5b. Hardness and resilience tests for all compounds are shown in Figure 6.

As Figure 5a shows the tensile strength of both SP3 and SP2 compounds increase in comparison with SP1 and

Table 5. The results of tensile, hardness and resilience properties of three different samples

\begin{tabular}{lcccccc}
\hline Sample & $\begin{array}{c}\text { Tensile } \\
\text { Strength (MPa) }\end{array}$ & $\begin{array}{c}\text { Modulus100\% } \\
(\mathbf{M P a})\end{array}$ & $\begin{array}{c}\text { Modulus 300\% } \\
(\mathbf{M P a})\end{array}$ & $\begin{array}{c}\text { Elongation } \\
\mathbf{( \% )}\end{array}$ & $\begin{array}{c}\text { Hardness } \\
\text { (Shore A) }\end{array}$ & $\begin{array}{c}\text { Resilience } \\
(\%)\end{array}$ \\
\hline SP1 & 14.07 & 2.35 & 7.71 & 491 & 58 & 47 \\
SP2 & 17.80 & 1.65 & 6.30 & 639 & 54 & 56 \\
SP3 & 17.65 & 2.76 & 9.50 & 504 & 60 & 49 \\
\hline
\end{tabular}


they are not significantly different from each other. So Perkalink900 and SS-Calix have the same effect on tensile strength of rubber products. It seems that due to the macromolecule structure of the SS-Calix and the presence of many hydroxyl groups and cavities in this system, polymer chains have been interacted with SS-Calix. As a result, the compound structure has become tighter, therefore the tensile strength has increased in comparison with SP1 compound. Figures 5a and 6 show that the highest modulus and hardness is related to SP3 rubbery compound and the lowest modulus and hardness is related to SP2. In fact, Perkalink900 has a negative effect on modulus and hardness. The increase in modulus and hardness in SP3 blend is due to the increase in crosslink density in this compound. Increasing the density of crosslinks also reduces the elongation and resilience of SP3 (Figures $5 b$ and 6). It should be noted that the crosslink density effect on the tensile strength, modulus, elongation at break, resilience and hardness. ${ }^{29-31}$

\section{3. The Thermal Gravimetric Analysis}

In order to investigate the thermal resistance of three different compounds thermal gravimetric was performed. Figure 7 show the weight loss behavior for all compounds.

The data of thermal analysis for all samples are summarized in Table 6. The results show that the onset temperature of degradation of SP2 is lower than that of SP3 and this process continues up to $45 \%$ of degradation. After that, the destruction temperature of both samples up to $90 \%$ is almost the same. However, due to chemical and physical interactions between SS-Calix and SP3 blend it

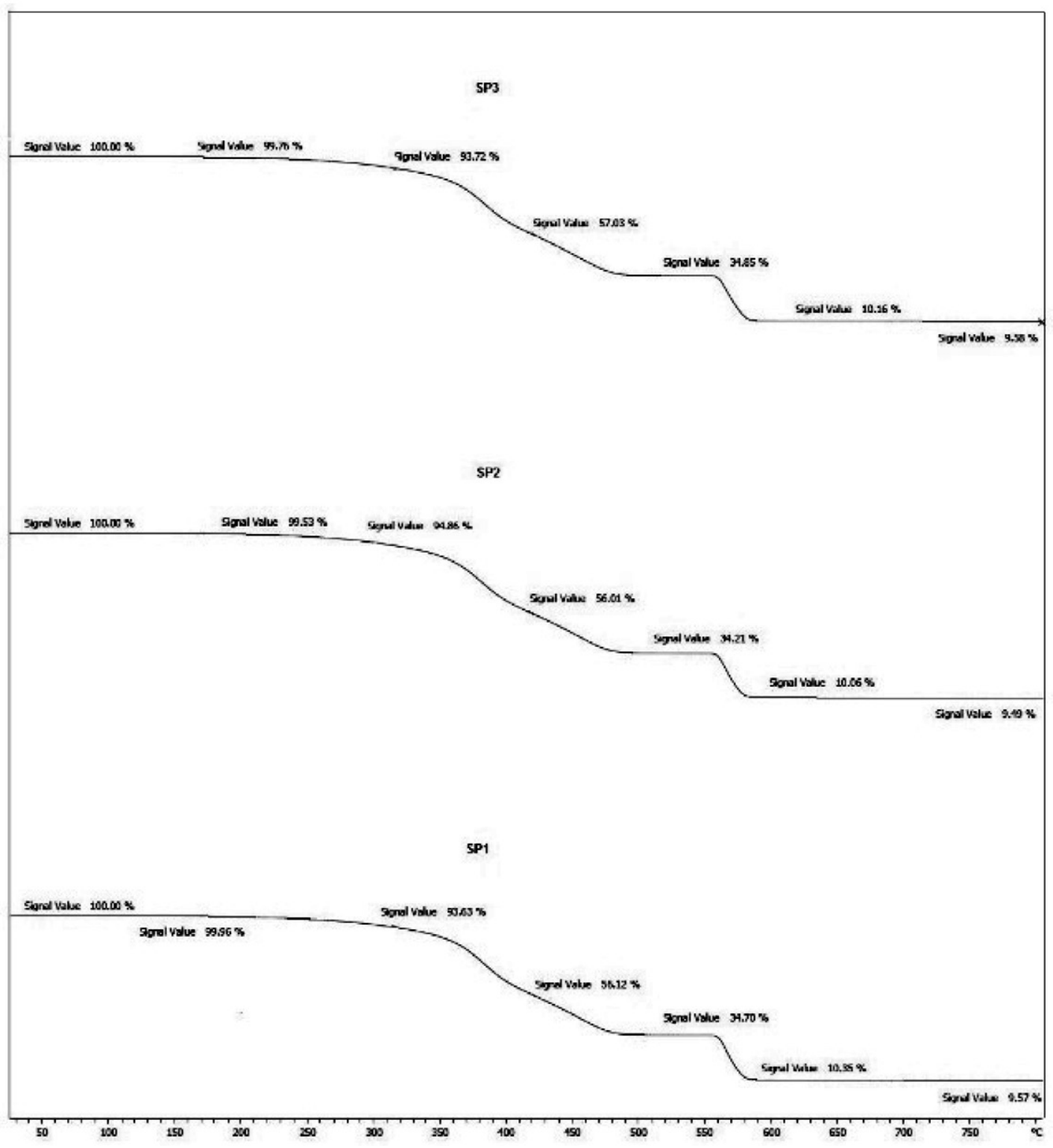

Figure 7. The weight loss behavior of SP1, SP2 and Sp3 specimens 
Table 6. The TGA data for three different samples

\begin{tabular}{lccc}
\hline & \multicolumn{3}{c}{ Sample } \\
& SP1 & SP2 & SP3 \\
\hline $\mathrm{T}_{\text {in }}\left({ }^{\circ} \mathrm{C}\right)$ & 320 & 290 & 320 \\
$\mathrm{~T}_{5 \%}\left({ }^{\circ} \mathrm{C}\right)$ & 329 & 310 & 329 \\
$\mathrm{~T}_{15 \%}\left({ }^{\circ} \mathrm{C}\right)$ & 370 & 360 & 380 \\
$\mathrm{~T}_{25 \%}\left({ }^{\circ} \mathrm{C}\right)$ & 386 & 378 & 388 \\
$\mathrm{~T}_{35 \%}\left({ }^{\circ} \mathrm{C}\right)$ & 402 & 392 & 408 \\
$\mathrm{~T}_{45 \%}\left({ }^{\circ} \mathrm{C}\right)$ & 431 & 419 & 435 \\
$\mathrm{~T}_{50 \%}\left({ }^{\circ} \mathrm{C}\right)$ & 442 & 442 & 445 \\
$\mathrm{~T}_{55 \%}\left({ }^{\circ} \mathrm{C}\right)$ & 461 & 451 & 452 \\
$\mathrm{~T}_{65 \%}\left({ }^{\circ} \mathrm{C}\right)$ & 561 & 480 & 482 \\
$\mathrm{~T}_{75 \%}\left({ }^{\circ} \mathrm{C}\right)$ & 570 & 569 & 570 \\
$\mathrm{~T}_{85 \%}\left({ }^{\circ} \mathrm{C}\right)$ & 580 & 573 & 580 \\
$\mathrm{~T}_{95 \%}\left({ }^{\circ} \mathrm{C}\right)$ & 582 & 580 & 582 \\
\hline
\end{tabular}

seems reasonable that the thermal resistance of SP3 is higher than that of SP2.

\section{4. Fourier Transform Infrared Spectroscopy (FTIR)}

The FTIR for all compounds were showed in Figure 8.

The Fourier transform infrared spectroscopy was performed to evaluate the anti-reversion behavior of SP3 blend. Since the interpretation of the FTIR spectrum of rubber samples is so complex, only strong bands were considered in this study.

The absorption curves of the SP3 blend showed that in addition to the bands characteristic for calix [4] arenes, ${ }^{27}$ there is a broad peak around $1824 \mathrm{~cm}^{-1}$ which is referred to $\mathrm{C}=\mathrm{O}$ bond.$^{32}$ As we know, the most important feature of SS-Calix is the position of the $\mathrm{OH}$ stretching bond in the $3100-3500 \mathrm{~cm}^{-1}$ region. The considerably weaker $\mathrm{C}=\mathrm{O}$ bond for SP1 and SP2 blends is attributed to the fact that the oxygen of hydroxyl groups of the calixarene surface forms a $\mathrm{C}=\mathrm{O}$ with the carbon in the polymer chain. ${ }^{33}$

\section{5. The Conversion Rate of Vulcanization}

By using equation (2), the conversion rate of vulcanization at various times had evaluated for all compounds (Table 7). ${ }^{34}$

$$
\mathrm{Xt}=\frac{\mathrm{Mt}-\mathrm{ML}}{\mathrm{MH}-\mathrm{ML}}
$$

In this equation, $\mathrm{Xt}$ indicate the conversion rate at the given time $\mathrm{t}$. Mt, MH, ML and MH-ML represent torque at the given time $t$, the maximum Torque, the Minimum Torque and the difference between maximum and minimum Torque, respectively.

The value of $\mathrm{X}_{5}$ indicate the delay in scorch time for SP3 specimen compared to SP2. The conversion ratio of $\mathrm{SP} 1$ and SP3 at $\mathrm{X}_{13}$ equaled 1, which revealed that $\mathrm{Mt}=\mathrm{MH}$

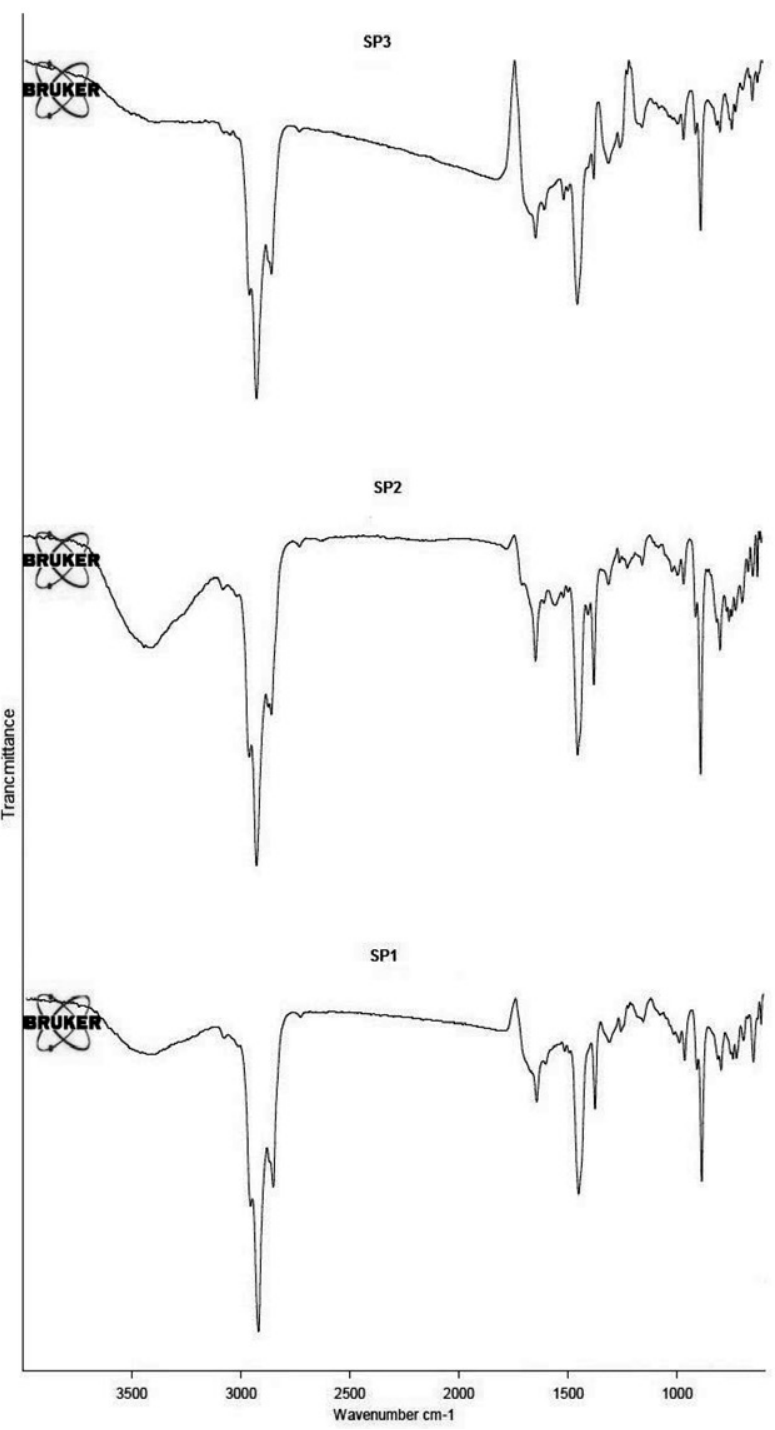

Figure 8. The FTIR for SP1, SP2 and Sp3 specimens

Table 7. The conversion rate of vulcanization at various times for all compounds

\begin{tabular}{llll}
\hline & \multicolumn{3}{c}{ Sample } \\
& SP1 & SP2 & SP3 \\
\hline $\mathbf{X}_{\mathbf{5}}$ & 0.05 & 0.05 & 0.03 \\
$\mathbf{X}_{\mathbf{1 0}}$ & 0.95 & 0.85 & 0.86 \\
$\mathbf{X}_{\mathbf{1 3}}$ & 1.00 & 0.98 & 1.00 \\
$\mathbf{X}_{\mathbf{1 4}}$ & 0.98 & 1.00 & 1.00 \\
$\mathbf{X}_{\mathbf{1 5}}$ & 0.96 & 0.98 & 0.98 \\
$\mathbf{X}_{16}$ & 0.96 & 0.98 & 0.98 \\
$\mathbf{X}_{\mathbf{1 7}}$ & 0.94 & 0.96 & 0.98 \\
$\mathbf{X}_{\mathbf{1 8}}$ & 0.94 & 0.96 & 0.96 \\
$\mathbf{X}_{\mathbf{2 0}}$ & 0.91 & 0.96 & 0.95 \\
$\mathbf{X}_{\mathbf{2 2}}$ & 0.89 & 0.96 & 0.95 \\
$\mathbf{X}_{\mathbf{2 4}}$ & 0.87 & 0.94 & 0.93 \\
$\mathbf{X}_{\mathbf{2 6}}$ & 0.85 & 0.93 & 0.91 \\
$\mathbf{X}_{\mathbf{2 8}}$ & 0.85 & 0.93 & 0.91 \\
$\mathbf{X}_{\mathbf{3 0}}$ & 0.84 & 0.91 & 0.90 \\
\hline
\end{tabular}


and the $90 \%$ of curing is done, for SP2 sample it happened in the $\mathrm{X}_{14}$, While for SP3 sample in $\mathrm{X}_{14}$ still remains 1 . The SP3 conversion rate up to $\mathrm{X}_{17}$ almost is more than SP2 (Table 7). These findings predicted that;

I: The reversion resistance of SP3 up to about $\mathrm{X}_{17}$ is more than SP2 and SP1.

II: The second important point is that after $\mathrm{X}_{17}$ up to $\mathrm{X}_{30}$, less reversion occurs for SP2.

III: The SP3 rubber sample exhibits high thermal resistance in a short time.

These outcomes confirm the result from curing behavior of three different samples.

\section{Conclusion}

Since the reversion has an undesirable effect on the performance properties of the rubber compounds, this study investigated the influence of the presence of SS-Calix as a novel anti-reversion on the reversion resistance of rubber blend based on NR/BR. Its anti-reversion properties were also compared with perkalink900. Finally, the following results are obtained:

- The presence of SS-Calix in compound based on NR/ $\mathrm{BR}$ increase the modulus and hardness also decrease the resilience and the elongation.

- In a few minutes after the start of reversion the reversion resistance effect of the SS-Calix was much better than perkalink900.

- The presence of SS-Calix increases the formation of $\mathrm{C}=\mathrm{O}$ bonds in SP3 sample that cause to increase reversion resistance in the early minutes after the start of reversion.

- Application of the SS-Calix to NR/BR rubber products subject to thermal shock is recommended.

- In NR/BR rubber compound that contains SS-Calix the initial temperature degradation until $\mathrm{T}_{45 \%}$ are more than perkalink 900 .

Based on these findings, it can be predicted that this feature of calix[4]arene can be applied in the preparation of rubber products that must have high thermal resistance in a short time.

\section{Reference}

1. B. Rodgers, (Ed.): Rubber Compounding Chemistry and Application, Marcel Dekker, New York, 2004, p.512.

DOI:10.1201/9781420030464

2. K. Boonkerd, CH. Deeprasertkul, K. Boonsomwong, Rubber. Chem. Technol. 2016, 89, 3, 450-464.

DOI: $10.5254 /$ rct. 16.85963

3. E. Leroy, A. Souid, A. Sarda, R. A. Deterre, Polym. Test. 2013, 32, 1, 9-14. DOI:10.1016/j.polymertesting.2012.08.012

4. P. M Visakh, S. Thomas, A. K. Chandra, A. P. Mathew, (Ed.): Advances in Elastomers I Blends and Interpenetrating Net- works, Springer, Heidelberg, New York Dordrecht London, 2013, pp. 121. DOI:10.1007/978-3-642-20925-3

5. S. Rabiei, A. Shojaei, Eur. Polym. 2016, 81, 98-113. DOI:10.1016/j.eurpolymj.2016.05.021

6. N. R. Kumar, A. K. Chandra, R. Mukhopadhyay, J. Mater. Sc. 1997, 32, 3717-3725. DOI:10.1023/A:1018655102644

7. R. N. Datta, N. M. Huntink, S. Datta, A.G. Talma, Rubber. Chem. Technol. 2007, 80, 3, 436-480.

DOI: $10.5254 / 1.3548174$

8. Sh. G. Sathi, J. Jeon, J. Won, Ch. Nah, J. Polym. Res. 2018, 25.

9. E. Leroy, A. Souid, R. Deterre, Polym. Test. 2013, 32, 3, 575582. DOI:10.1016/j.polymertesting.2013.01.003

10. G. Milani, E. Leroy, F. Milani, R. Deterre, Polym. Test. 2013, 32, 6, 1052-1063.

DOI:10.1016/j.polymertesting.2013.06.002

11. Sh. Gopisathi, Ch. Park, Y. I. Huh, J. Jeon, Ch. H. Yun, J. Won, K.U. Jeong, Ch. Nah, Rubber. Chem. Technol. 2019, 92, 1, 110-128. DOI:10.5254/rct.18.82605

12. G. S. Shibulal, J.Y. Jang, H. Ch. Yu, Y. I. Huh, Ch. Nah, J. Polym. Res. 2016, 23. DOI:10.1007/s10965-016-1128-9

13. F. D. B. de Sousa, A. Zanchet, C. H. Scuracchio, J. Appl. Polym. Sci. 2017, 134, 41. DOI:10.1002/app.45325

14. G. Milani, G. Milani, F. Milani, J. Math. Chem. 2015, 53, 1363-1379. DOI:10.1007/s10910-015-0493-7

15. S. Taghvaei-Ganjali, R. Zadmard, M. Zeyaei, K. Rahnama, F. Faridbod, M. R. Ganjali, Lett. Org. Chem. 2009.

DOI:10.1155/2009/601089

16. M. Hosseini, M. Rahimi, H. Bagheri Sadeghi, S. TaghvaeiGanjali, Sh. Dehghan Abkenar, M. R. Ganjali, Intern. J. Environ. Anal. Chem. 2009, 89, 6, 407-422.

DOI:10.1080/03067310802713195

17. M.S. Mirmoeini, M. M. Alavi Nikje, M. Rasouli-Saniabadi, S. Taghvaei-Ganjali, Macromol. Symp. 2017, 373.

DOI:10.1002/masy.201600101

18. S. Taghvaei-Ganjali, M. Rasouli-Saniabadi, M.S. Mirmoeini, J. Inc. Phenom. Macro. 2015, 83, 45-52.

DOI:10.1007/s10847-015-0539-2

19. M. Nouri, Sh. Mozafari, S. Taghvaei-Ganjali, Iran. JOC. 2011, 3, 4, 807-809.

20. K. D. Daze, C. E. Jones, B. J. Lilgert, C. S. Beshara, F. Hof, Can. J. Chem. 2013, 91, 1072-1076.

DOI:10.1139/cjc-2013-0186

21. T. T. Pang, L. M. Du, H. L. Liu, Y. L. Fu, Can. J. Chem. 2014, 92, 1139-1144. DOI:10.1139/cjc-2014-0150

22. H. Mohamadi, F. Motiee, M. Saber-Tehrani, S. Taghvaei-Ganjali, Russ. J. App. Chem. 2019, 92, 809-816.

DOI:10.1134/S1070427219060107

23. M. Malekzadeh, H. Nouri, M. Farahani, JACR. 2010, 3, 41-45.

24. H. Margharian Pekachaki, S. Taghvaei-Ganjali, F. Motiee, M. Saber-Tehrani, Rubb. Chem. Technol. 2019, 92, 3, 467-480. DOI: $10.5254 /$ rct.19.81510

25. Z. Servati, M. Saber-Tehrani, S. Taghvaei-Ganjali, R. Zadmard, J. Porous. Mater. 2018, 25, 1463-1474.

DOI:10.1007/s10934-018-0559-6

26. H. Li, Y. Zhong, W. Wu, L. Zhang, X. Lai, X. Zeng, J. Appl. Polym. Sci. 2017, 134, 31. 
27. S. Taghvaei-Ganjali, R. Zadmard, M. Saber-Tehrani, Appl. Surf. Sci. 2012, 258, 16, 5925-5932.

DOI:10.1016/j.apsusc.2011.09.019

28. P. J. Flory, J. Rehner, J. Chem. Phys. 1943, 11, 521-526. DOI:10.1063/1.1723792

29. L. M. Polgar, G. Fortunato, R. Araya-Hermosilla, M. van Duin, A. Pucci, F. Picchioni, Eur. Polym. J. 2016, 82, 208-219. DOI:10.1016/j.eurpolymj.2016.07.018

30. S. S. Choi, H. M. Kwon, Y. Kim, E. Ko, K. S. Leeb, Polym. Int. 2018, 67, 3, 340-346. DOI:10.1002/pi.5515
31. I. Surya, H. Ismail, A.R. Azura, Polym. Test. 2015, 42, 208214. DOI:10.1016/j.polymertesting.2014.12.009

32. M. Fan, Y. Zhang, X. Li, B. Zeng, Sh. Chen, W. Zhu, Sh. Wang, J. Xu, N. Feng, Polym. Advan. Technol. 2019, 30, 5. DOI:10.1002/pat.4555

33. C. D. Gutsche, in: Calixarenes, Royal Society of chemistry, Cambridge, 2008, p.70.

34. K. Chawla, A. P. S. Chauhan, A. Pandey, Plast. Rubber. Compos. 2016, 45, 6. DOI:10.1080/14658011.2016.1178969

\section{Povzetek}

Raziskali smo vpliv silikatnega nosilca ojačanega s kaliks [4] arenskim drivatom (SS-Calix) na zmanjševanje zamreženja, mehanske lastnosti in termično obnašanje NR/BR pnevmatik s pomočjo reometra z oscilacijskim diskom, FTIR, TGA in napetostnega testa. Rezultati so pokazali, da je zmanjševanje zamreženja NR/BR vulkanizata odvisno od dodatka SS-Calix-a. Rezultati pridobljeni iz meritev značilnosti zamreževanja in termične stabilnosti testiranih vzorcev so pokazali, da SS-Calix deluje kot preprečevalec zmanjševanja zamreženja za gumijaste materiale izpostavljene termičnemu šoku v zgodnjih fazah naraščanja temperature. Predpostavljamo, da so opažene lastnosti posledica interakcij med OH skupinami prisotnimi na SS-Calix-u in ogljikom v polimernih verigah. Širok vrh opažen na IR spektru okoli $1824 \mathrm{~cm}^{-1}, \mathrm{ki} \mathrm{je}^{-}$ značilen za $\mathrm{C}=\mathrm{O}$ vez, potrjuje to predpostavko. Poleg tega prisotnost SS-Calix-a povečuje napetostni modul in trdoto a hkrati zmanjšuje raztegljivost in odpornost. 